American Journal of Applied Sciences 7 (4): 545-550, 2010

ISSN 1546-9239

(c) 2010Science Publications

\title{
Impact of Earthquake Demolition Debris on the Quality of Groundwater
}

\author{
M.S. Benmenni and K. Benrachedi \\ Laboratory of Food Technology, Faculty of Engineer Sciences, \\ University of Boumerdes, 35000 Boumerdes Algeria
}

\begin{abstract}
Problem statement: Debris from construction or demolition/deconstruction processes have no significant impact on the environment as they are res-usable and inert. This has been also long admitted for solid waste generated by the demolition of damaged cities following violent earthquakes. Approach: This study is a contribution to the assessment of actual impact on the quality of groundwater of buried demolition debris from the city of Boumerdes, in the North of Algeria 5 years after the May 21st 2003 earthquake hit the region. The public discharge of Boumerdes city has been used as a temporary landfill. It is located about $5 \mathrm{~km}$ downtown of Boumerdes at the Tidjelabine site which is marly-calcareous formation. Leachate from the landfill was directly rejected in the receiving environment, where the soil is marly-calcareous type with cracks giving a variable permeability $\left(10^{-2}\right.$ $\mathrm{m} \mathrm{sec}^{-1}$ to nearly $10^{-6} \mathrm{~m} \mathrm{sec}^{-1}$ ) that facilitates infiltration of potential pollutants to the groundwater. The slope character (from 5-10\%) of the field contributes to pollutants movement and may accentuate water quality deterioration. Three domestic wells (designated S1, S2 and S3) were selected in the vicinity of the landfill and served as piezometers. Leachate samples were taken from the landfill and evaluated. Results: Leachate analysis indicated organic matter with relatively high COD (1136 mg L $\mathrm{L}^{-1}$ $\mathrm{O}_{2}$ ) and $\mathrm{BOD}_{5}\left(200 \mathrm{mg} \mathrm{L}^{-1} \mathrm{O}_{2}\right)$; whereas the $\mathrm{pH}$ yielded 7.65 thus indicating fermentation phase of the landfill. Heavy metal contents were beyond national standard limits except for Pb with $0.51 \mathrm{mg} \mathrm{L}^{-1}$ which is slightly higher than limit value of $0.5 \mathrm{mg} \mathrm{L}^{-1}$. More than five years after the creation of this landfill and despite its predominant C\&D nature, these results showed that it was following a typical urban wastes decomposition scheme. Same analysis carried on water samples drawn from the piezometers yielded following results: acidic $\mathrm{pH}$ (6.88), acceptable values of target heavy metals concentrations except for $\mathrm{Zn}$ with $0.779 \mathrm{mg} \mathrm{L}^{-1}$. Additionally bacteriological cross analysis (membrane filter and multi-tube methods) showed groundwater contamination by total coliforms $(1100 / 100 \mathrm{~mL})$, fecal coliforms $(11 / 100 \mathrm{~mL})$ and fecal streptococci $(1100 / 100 \mathrm{~mL})$. Conclusion: These results proved that leachate had reached the first aquifer horizon about $10 \mathrm{~m}$ beneath soil surface. Prior to any remediation program, Management of Boumerdes Municipality is called to quickly implement a reuse and recycling program of the demolition debris in order to stop water reservoirs contamination source.
\end{abstract}

Key words: Demolition debris, landfill, leachate, heavy metals, groundwater, infiltration

\section{INTRODUCTION}

The solid waste management is governed by standards the user must respect otherwise they expose themselves to pollution that may follows. For instance, it is common sense, that water pollution may be due to industrial effluents such as exhaust fumes and gases liquid or solid wastes that strongly contribute to water quality impoverishment. Same applies for extensive agriculture which requires fertilizers that induce increasing water pollution risks.
But, the pollution generated by solid waste from house demolition has long been underestimated as presenting no danger in the short term (Brunner and Stampfil, 1993; Tranklerlsa Walker and Dohmann, 1996).

This study is a contribution for the assessment the impact on groundwater pollution by demolition debris generated by the may 21rd, 2003 earthquake of Boumerdes. To face the emergency and urgency, demolition debris were quickly buried in temporary

Corresponding Author: M.S. Benmenni, Laboratory of Food Technology, Faculty of Engineer Sciences, University of Boumerdes, 35000 Boumerdes Algeria 
sites (which still remain untreated) in places that poses no difficulty for approval (generally state owned agricultural lands) without any preliminary study of impact. Indeed, this disaster has caused severe damage to facilities that generated tens of millions of tons of debris and rubble. Thus, there are 22 landfills totalizing some 30 million cubic meters and occupying a total area of 100 ha.

Our study focuses on the landfill of the city of Boumerdes and surrounding communities (Boudouaou, Corso, Figuier and Tidjelabine), where debris of more than 23.00 demolished homes have been stored.

This landfill is suspected to affect the quality of surface and underground as rainfalls generate leaching of stored debris which, in turn, generate lixiviates that infiltrate the soil and cause chemical pollution of water by the ETM. All of these inter-actions between the dump and the receiving environment exacerbate the risks of pollution.

Our investigation concerns cross impact of possible pollution by the landfill on:

- Health and environment caused by unpleasant smoke and odor and toxic fume inhalation

- Water and soil contamination caused by lixiviates
Location of landfill: There are five landfills for Boumerdes and its communities, one in Tidjelabine, two in Figuer another one in Corso and the last one in Boudouaou.

Figure 1 shows maps the different landfills across the territory of the Wilaya of Boumerdes and Fig. 2 shows the location of the landfills of the city of Boumerdes and its communities.

All of these sites are in the form of low slope of about $5-10 \%$ and covers an area of 10 ha, whereas their altitude varies between 850 and $900 \mathrm{~m}$.

The slope promotes water runoff. Indeed, lixiviate or rainwater entering the waste is the source of runoff processes favoring pollution by infiltration through limy/sandy soil cracks. The selection of any current site for demolition debris land-filling obeyed only to criteria of accessibility and proximity.

Hydrological and geological context: The geological formations at the outcrop in the studied area consist of marls with intercalations of fissured limestone and alluvium, respectively, of Cretaceous age and Mio-Plio-Quaternary.

These formations give the sites a variable permeability in the horizontal and vertical directions.

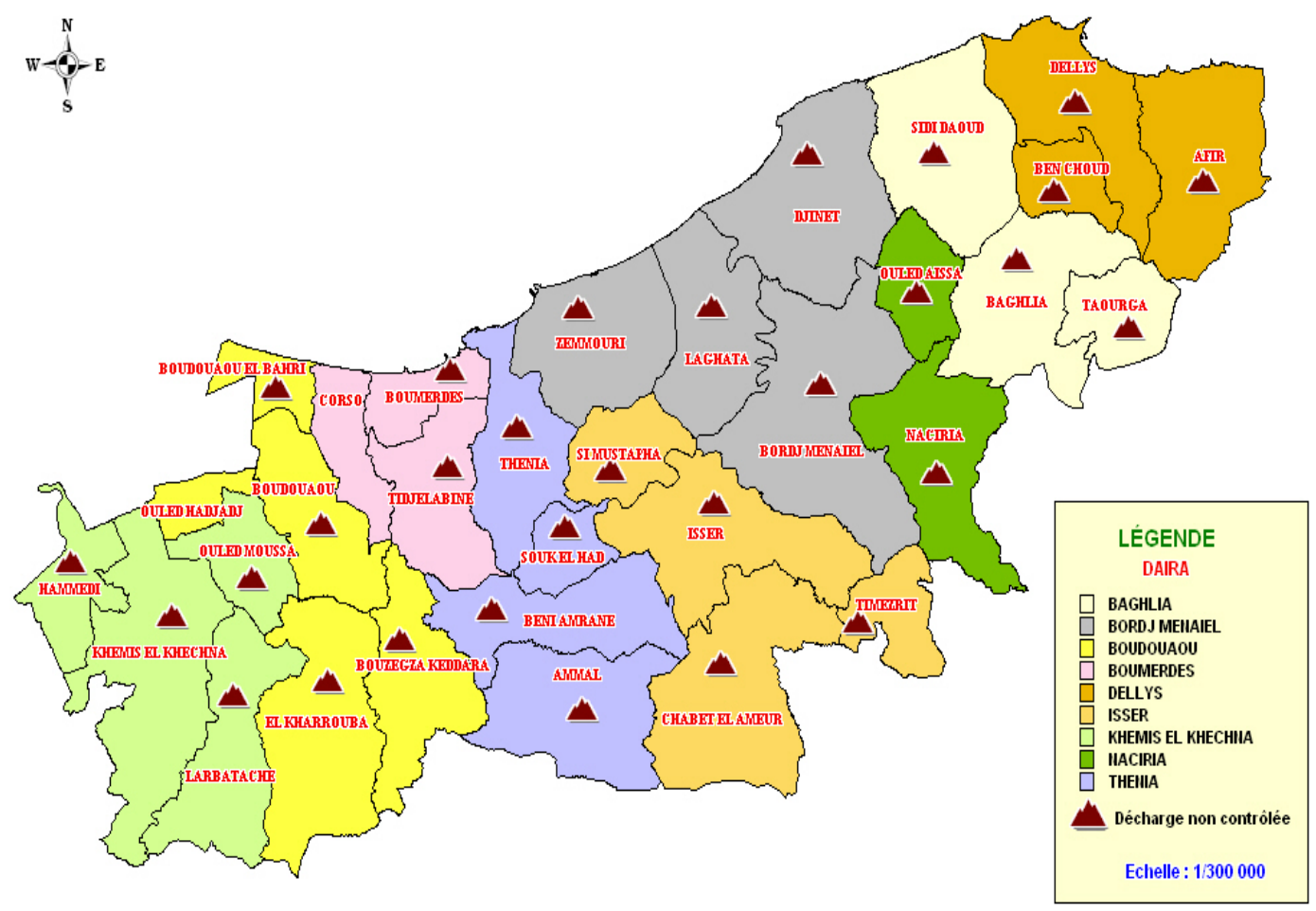

Fig. 1: Map of the Wilaya of Boumerdes and its 22 temporary landfills 
Indeed, frequent feature changes (transition from alluvial formation to cracked or compact limestone) are the reason for important variation in permeability.

As a matter of fact, we switch from a permeability of about $10^{-2} \mathrm{~m} \mathrm{sec}^{-1}$ to nearly $10^{-6} \mathrm{~m} \mathrm{sec}^{-1}$.

Thus, the flow directions follow existing cracks.

However, the hydro-geological studies conducted in the area shows that there are two aquifer horizons. The first one has a relatively short depth (maximum $10 \mathrm{~m}$ ), the alluvial Mio-Plio-Quaternary being its bottom seat and which may be polluted by inputs from the landfill. The second one is deeply located across the valangian-Albian sandstone.

Precipitations in the area average $410.5 \mathrm{~mm}_{\text {year }}{ }^{-1}$ (2005/2006) and accentuate the movement of pollutants either through infiltration or by surface runoff.

Waste characterization: The town of Boumerdes covers an area of 1800 ha occupied by inhabitants (2005).

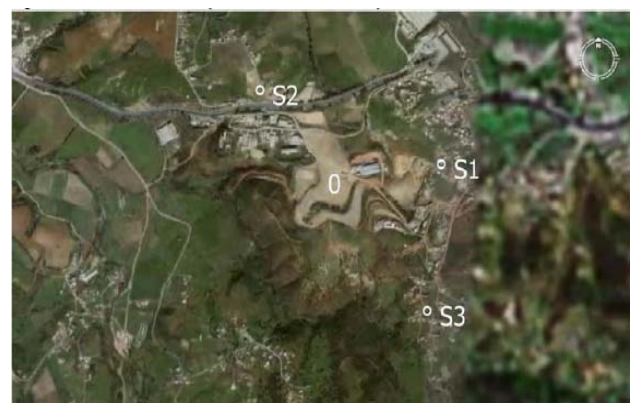

Fig. 2: Location of the Tidjelabine landfill of the city of Boumerdes

Table 1: Tonnage estimation of the most prevalent material types in disposed wastes

\begin{tabular}{lrr}
\hline Material type & Est. Mass (tons) & \multicolumn{1}{c}{ (\%) } \\
\hline Concrete (including iron framework) & 399140 & 54.30 \\
Bricks (clay) & 6200 & 0.85 \\
Gypsum & 12680 & 1.75 \\
Paints and wall coatings & 2500 & 0.35 \\
Lumber & 3690 & 0.50 \\
Plastics* & 63616 & 8.65 \\
Household waste** & 212055 & 28.85 \\
Miscellaneous*** & 35342 & 4.80 \\
\hline
\end{tabular}

Tidjelabine landfill; *: Mainly beverage containers, grocery and trash bags, films and durable items; **: Includes food rests, stale fruits and vegetables leaves and grass, paper, textile, glass, plastic bags, domestic appliances and other small consumer electronics; ***: Includes used vehicle parts, batteries, used oil, ash, electronics, tires, asphalt, industrial sludge, glass
The estimated masses (tons) of various types of debris buried in the site is given in Table 1 (Yost and Halstead, 1993).

\section{MATERIELS AND METHODS}

In our study, a sampling campaign and analysis was performed on the leachate from the landfill and three control wells that serve as piezometers. The collection is made to the month of March 2007 and covered the major ions, heavy metals, nitrogen, chemical applications and biological oxygen demand $\left(\mathrm{COD}\right.$ and $\left.\mathrm{BOD}_{5}\right)$, organic matter and minerals and microbiological analysis of groundwater. Temperature, $\mathrm{pH}$ and conductivity were measured on site.

The three wells designated S1, S2 and S3, as indicated in Fig. 2, were selected near the discharge. Table 2 gives information concerning the status of wells from the landfill. The proximity of the wells from the landfill centre is important because they are more liable and vulnerable to all forms of pollution.

\section{Leachate:}

The composition of leachate from a landfill: Landfill leachate is similar to complex industrial waste containing both contaminating substances: organic and inorganic. Often, the inorganic contaminants are very toxic. Thus, their composition varies depending on the nature of waste, age of discharge, the technical operating and climatic conditions. Leachate may come from either waste water or rain weather and also from the water of the aquifer (Benz et al., 1997).

\section{RESULTS}

The color is the first indicator of pollution. The analyzed leachate taken downstream of the landfill has a brownish color and a faecal smell, thus influencing the quality of groundwater. Results of leachate analysis are reported in Table 3. Heavy metals concentrations are compared with values of similar landfills in Table 4. Results of physical and chemical analysis of groundwater samples are given in Table 5, while their cross bacteriological states are given in Table 6 and 7. Finally, Table 8 compares target heavy metals yields found in leachate with those in groundwater of the site.

Table 2: Localization and use of the selected piezomters close to the Tidjelabine discharge

\begin{tabular}{lll}
\hline Designation of taking point & Situation vis-a-vis centre $(\mathrm{O})$ of the landfill & Distance (m) from O \\
\hline S1 & East. Well of 2 m depth domestic use piezometer. & 300 \\
S2 & North in residential. Well of 8 m depth domestic use & 350 \\
S3 & South West in agricultural land. Well of 8 m depth irrigation use & 420 \\
\hline
\end{tabular}


Am. J. Applied Sci., 7 (4): 545-550, 2010

Table 3: Results of leachate samples analysis Tidjelabine discharge

\begin{tabular}{|c|c|c|c|c|c|}
\hline Concentrations & Sample1 & Sample 2 & Sample 3 & Sample 4 & IANOR standard \\
\hline pH & 7.370 & 7.50 & 7.65 & 6.940 & $6.5-8.5$ \\
\hline DCO in $\mathrm{mg} \mathrm{L}^{-1}$ & 36.400 & 1136.00 & 53.76 & 980.98 & 120.0 \\
\hline $\mathrm{DBO}_{5}$ in $\mathrm{mg} \mathrm{L}^{-1}$ & 8.100 & 198.90 & 1.60 & 145.60 & 35.0 \\
\hline MES in $\mathrm{mg}^{-1}$ & 12.000 & 10.00 & 16.00 & 10.000 & 35.0 \\
\hline Nitrates in $\mathrm{mg} \mathrm{L}^{-1}$ & 0.300 & 0.10 & 0.30 & 0.200 & 50.0 \\
\hline Nitrites in $\mathrm{mg} \mathrm{L}^{-1}$ & 0.016 & 0.01 & 0.02 & 0.002 & 0.1 \\
\hline Chlorures in $\mathrm{mg} \mathrm{L}^{-1}$ & 62.400 & 60.98 & 31.19 & 25.520 & 500.0 \\
\hline Sulfates in $\mathrm{mg} \mathrm{L}^{-1}$ & 75.000 & 75.00 & 43.00 & 64.000 & 400.0 \\
\hline Phosphates in $\mathrm{mg} \mathrm{L}^{-1}$ & 13.000 & 8.00 & 0.39 & 0.740 & 10.0 \\
\hline Ammoniacal nitrogen in $\mathrm{mg} \mathrm{L}^{-1}$ & 0.010 & 0.02 & 0.01 & 0.040 & 30.0 \\
\hline $\mathrm{Pb}$ in $\mathrm{mg} \mathrm{L}^{-1}$ & 5.890 & 0.02 & $<0.01$ & 0.510 & 0.5 \\
\hline $\mathrm{Zn}$ in $\mathrm{mg} \mathrm{L}^{-1}$ & 6.700 & 0.16 & $<0.01$ & 0.470 & 3.0 \\
\hline $\mathrm{Cd}$ in $\mathrm{mg} \mathrm{L}^{-1}$ & $<0.010$ & $<0.01$ & $<0.01$ & 2.780 & 0.2 \\
\hline $\mathrm{Cu}$ in $\mathrm{mg} \mathrm{L}^{-1}$ & $<0.010$ & $<0.01$ & $<0.01$ & $<0.010$ & 0.5 \\
\hline
\end{tabular}

Table 4: Comparison of the levels of heavy metals in landfill leachate

\begin{tabular}{llllll}
\hline Target metal mg/l & Tiaret & El jedida & Wadi akrech & Eteffont & Tidjelabine \\
\hline $\mathrm{Zn}$ & 0.50 & 0.0474 & 0.700 & 0.740 & 6.700 \\
$\mathrm{Cu}$ & - & 0.1580 & 0.450 & 0.270 & 0.050 \\
$\mathrm{Ni}$ & 0.60 & 0.1330 & 0.250 & 0.210 & 6.700 \\
$\mathrm{Cr}$ & 0.30 & 0.1560 & 0.500 & 0.270 & 3.400 \\
\hline
\end{tabular}

Table 5: Results of physical-chemical analysis of groundwater

\begin{tabular}{lccc}
\hline Parameters & $\mathrm{S} 1$ & $\mathrm{~S} 2$ & $\mathrm{~S} 3$ \\
\hline $\mathrm{pH}$ & 6.3700 & 6.5600 & 6.8500 \\
$\mathrm{~T}{ }^{\circ} \mathrm{C}$ & & & - \\
$\mathrm{CO}_{3}{ }^{2-} \mathrm{mg} \mathrm{L}^{-1}$ & - & - & 48.0000 \\
$\mathrm{HCO}^{-} \mathrm{g} \mathrm{L}^{-1}$ & 540.5800 & 417.9700 & 488.000 \\
$\mathrm{Ca}^{2+} \mathrm{mg} \mathrm{L}^{-1}$ & 144.9200 & 116.7120 & 126.9730 \\
$\mathrm{Mg}^{2+} \mathrm{mg} \mathrm{L}^{-1}$ & 13.4200 & 39.4950 & 0.0000 \\
$\mathrm{Cl}^{-} \mathrm{mg} \mathrm{L}^{-1}$ & 209.1960 & 327.4800 & 98.8540 \\
$\mathrm{SO}_{4}^{2-} \mathrm{mg} \mathrm{L}^{-1}$ & 38.6810 & 139.0870 & 399.1550 \\
$\mathrm{MES}^{\mathrm{DCO}}$ & $0.3000 \times 10^{-2}$ & $1.7000 \times 10^{-2}$ & $0.7000 \times 10^{-2}$ \\
$\mathrm{BDO}_{5}$ & 74.0000 & 32.0000 & 82.0000 \\
$\mathrm{NO}_{2}{ }^{-} \mathrm{mg} \mathrm{L}^{-1}$ & 30.0000 & 20.0000 & 40.0000 \\
$\mathrm{PO}_{4}^{2-} \mathrm{mg} \mathrm{L}^{-1}$ & 0.0190 & 0.0100 & 0.0000 \\
$\mathrm{Metal}^{-1}$ & 0.0200 & 0.0400 & 0.1400 \\
$\mathrm{Cd} \mathrm{mg} \mathrm{L}^{-1}$ & & & \\
$\mathrm{Cu} \mathrm{mg} \mathrm{L}^{-1}$ & 0.0070 & 0.0078 & 0.0060 \\
$\mathrm{~Pb} \mathrm{mg} \mathrm{L}^{-1}$ & 0.0140 & 0.0047 & 0.0122 \\
$\mathrm{Zn} \mathrm{mg} \mathrm{L}$ & 0.0220 & 0.0000 & 0.0000 \\
\hline & 0.0790 & 0.0124 & 0.7790 \\
\hline
\end{tabular}

Table 6: Bacteriological composition of groundwater by the method of the membrane filter

\begin{tabular}{llll}
\hline Germs & well 1 & well 2 & well 3 \\
\hline Coliforms & Presence $>300$ & Presence $>$ 300 & Presence $>300$ \\
Fecal Coliformes & Presence & Presence & Presence \\
Fecal Streptococci & Presence & Presence & Presence \\
\hline
\end{tabular}

Table 7: Bacteriological composition of groundwater by the method of multiple tubes

\begin{tabular}{llll}
\hline Germs & well 1 & well 2 & well 3 \\
\hline Total Coliforms & $11 / 100 \mathrm{~mL}$ & $28 / 100 \mathrm{~mL}$ & $1100 / 100 \mathrm{~mL}$ \\
Fecal Coliforms & $11 / 100 \mathrm{~mL}$ & $3 / 100 \mathrm{~mL}$ & $7 / 100 \mathrm{~mL}$ \\
Fecal streptococci & $9 / 100 \mathrm{~mL}$ & $7 / 100 \mathrm{~mL}$ & $1100 / 100 \mathrm{~mL}$ \\
\hline
\end{tabular}

Table 8: Yields of heavy metals in leachate Vs groundwater

\begin{tabular}{lll}
\hline Heavy metal $\mathrm{mg} \mathrm{L}^{-1}$ & Leachate & Groundwater \\
\hline $\mathrm{Cd}$ & 2.78 & 0.078 \\
$\mathrm{Cu}$ & 0.10 & 0.014 \\
$\mathrm{~Pb}$ & 0.51 & 0.022 \\
$\mathrm{Zn}$ & 0.47 & 0.779 \\
\hline
\end{tabular}

\section{DISCUSSION}

We notice that the Chemical Oxygen Demand (COD) in leachate exceed widely accepted standards. Indeed, it is above the average standard of Algeria which is about $120 \mathrm{mg} \mathrm{L}^{-1}$ and reached $1136 \mathrm{mg} \mathrm{L}^{-1}$. As for $\mathrm{BOD}_{5}$, it varies between 135 and $200 \mathrm{mg} \mathrm{L}^{-1}$ whereas the accepted standard is $40 \mathrm{mg} \mathrm{L}^{-1}$, thus showing significant pollution. However, the actual concentration of $\mathrm{BOD}_{5}$ is still higher than the values found because the medium is loaded with toxins.

The concentrations of heavy metals (cadmium, chromium, zinc and nickel are beyond acceptable standards. The concentration of lead is at the limit of the standard. Heavy metals in leachate inhibit microbial growth.

The results of chemical characterization of raw leachate from Boumerdes landfill indicated a dual pollution:

- An organic pollution that results in a high load of COD in the leachate, in sample2 for instance, the COD is about $1136 \mathrm{mg} \mathrm{L}^{-1} \mathrm{O}_{2} \mathrm{~L}^{-1}$ and $\mathrm{BOD}_{5}$ is approximately $200 \mathrm{mg} \mathrm{L}^{-1} \mathrm{O}_{2} \mathrm{~L}^{-1}$

- A mineral pollution that results in high concentrations of some additional heavy metals in 
leachate, such as in sample1 for instance with values of $3.4 \mathrm{mg} \mathrm{L}^{-1}$ for $\mathrm{Cr}, 6.7 \mathrm{mg} \mathrm{L}^{-1}$ for $\mathrm{Ni}$ and $6.7 \mathrm{mg} \mathrm{L}^{-1}$ for $\mathrm{Zn}$

The metal composition of the leachate from the Boumerdes landfill seems to be typical of a landfill of household dominant character. Indeed, when comparing the concentrations of same metallic elements $(\mathrm{Cu}, \mathrm{Cr}$, $\mathrm{Ni}, \mathrm{Zn}$ ) to those of leachate generated by other garbage dumps in Tiaret (Algeria), Rabat (Marocco) or Eteffont (France), we find that the values are higher for the Tdjelabine landfill, except for $\mathrm{Cu}$.

Therefore it becomes essential to recover and treat the juice from the landfill to avoid any risk of environmental contamination by infiltration of the leachate.

Applied to the analyzed leachate from the landfill, the ratio $\mathrm{BOD}_{5} / \mathrm{COD}$ gives values ranging from 0.110.25 , typical of an ancient but not yet stabilized landfill and corresponding to the acid phase of anaerobic degradation (Salem et al., 2008).

Applied to the analyzed leachate from the landfill, the ratio gives values ranging from 0.11-0.25, typical of an ancient but not yet stabilized landfill and corresponding to the acid phase of anaerobic degradation.

Obtained results of analysis conducted on groundwater proved that the first aquifer (maximum 10 meters depth) has already been contaminated by leachate effluents, thus confirming its state and condition of polluted non-potable water.

As a matter of fact, both piezometers S1 and S2 contain weak acid waters $(\mathrm{pH}$ of 6.37 and 6.56 respectively) indicating the influence of the discharge on groundwater. On the other hand, S3 has a higher $\mathrm{pH}$ of 6.85, but still under neutrality.

For the other parameters, mainly dissolved oxygen, $\left(\mathrm{NO}_{3}, \mathrm{COD}, \mathrm{BOD}_{5}\right)$, levels are found prove low organic matters content in groundwater, but still are higher than the accepted standards of potable water. Pick concentrations of target metals ( 0.078 for Cd, 0.014 for $\mathrm{Cu}, 0.022$ for $\mathrm{Pb}$ and 0.779 for $\mathrm{Zn}$ ) in groundwater are higher than acceptable limits.

Two methods have been used for the evaluation of bacteriological composition of groundwater in order to insure more precise results. While the membrane filter method confirmed the presence of target germs, the multi-tubes one quantified them. Obtained results show that water wells contain important pathogens (Total Coliforms up to 1100, Fecal Coliforms up to 11 and Fecal streptococci up to 1100 per $100 \mathrm{~mL}$ ) showing a significant bacteriological contamination of groundwater. Well3 is the most polluted due to its location on the site. This latter is located downstream of the discharge and flows follow this direction. Furthermore, the permeability of cracks would promote the infiltration of leachate.

The temperature plays a very important role in increasing bacterial activity and evaporation of water. Indeed, temperature is a key element in the enumeration of aquifer systems. It varies depending on seasonal ambient temperature, the geological nature of the soil and the depth of the aquifer level under soil surface (Tranklerlsa Walker and Dohmann, 1996). In Tidjelabine case study temperature varies between 12 and $15^{\circ} \mathrm{C}$, thus low enough to avoid micro-organisms proliferation in groundwater, so the important presence of coliforms and fecal streptococci can only be explained as the result of contamination by leachate infiltration.

\section{CONCLUSION}

This study concerned the impact of debris and rubble from the demolition of cities following an earthquake and which were considered safe and inert. In the case of the Tidjelabine landfill, the results of the analysis conducted on leachate and water proved the dangerousness of this type of debris resulting in a real double impact on environment:

- A direct impact on surface water as rainfalls are polluted by leachate runoff promoted by slope configuration of the site

- An indirect impact as groundwater is polluted by leachate infiltrations through cracks of porous soil

The concentration of target heavy metals in leachate from the landfill is evolving towards a dominant municipal solid waste discharge, although it was, originally, a landfill for demolition and construction debris assumed to be inert (Durmusoglu and Yilmaz, 2006). A first explanation of this evolution may come from the presence of organic matters in the debris coming from demolished constructions by the earthquake at first hand, and from household waste later as the status of this discharge remained open for sometime after the earthquake.

The presence of germs in the piezometers shows that water is no more potable in the vicinity of the landfill, and users have been immediately informed about it. These results contribute to the enrichment of on the ground data concerning landfilled earthquake debris behavior.

Because of higher risk of contamination of our limited water resources due to leach toxicity of the 
debris (Sheridan et al., 2000), we strongly recommend the Management of Boumerdes to quickly address the issue through the implementation of a two-phase program:

- Reuse and recycling of the debris as a first priority, in order to eliminate the pollution source, followed by

- Remediation of the site in the second place, using appropriate treatments for heavy metals polluted soil and groundwater

\section{REFERENCES}

Benz, D., V.P. Singh and M. Akesson, 1997, Accumulation of water and generation of leachate in a young landfill. J. Hydrol., 203: 1-10.

Brunner, P. and D. Stampfil, 1993. Material balance of a construction waste sorting plant. Waste Manage. Res., 11: 453-461. DOI: 1006/wmre.1993.1005

Durmusoglu, E. and C. Yilmaz, 2006. Evaluation and temporal variation of raw and pre-treated leachate quality from an active solid waste landfill. Water, Air Soil Pollut., 171: 359-382. DOI: 10.1007/s11270-005-9061-2
Salem, Z., K. Hamouni, R. Djema and K. Allia, 2008. Evaluation of landfill leachate pollution and treatment. Desalination, 220: 108-114. DOI: 10.1016/.j.desal.2007.01.026

Sheridan, S.K., T.G. Townsend, J.L. Price and J.T. Connell, 2000. Policy options for hazardousbuilding-component removal before demolition. Pract. Period. Hazard. Toxic Radioact. Waste Manage., ASCE, 4: 111-117. DOI: 10.1061/(ASCE)1090-025\%(2000)4:3(111)

Tranklerlsa Walker, J.O.V. and M. Dohmann, 1996. Environmental impact of demolition waste: An overview on 10 years of research and experience. Waste Manage., 16: 21-26. DOI: 10.1006/S0956053X(96)00061-X

Yost, P.A. and J.M. Halstead, 1993. A methodology for quantifying the volume of construction waste. Waste Manage. Res., 11: 453-461. DOI: 1006/wmre.1993.1005 